\title{
Keefektifan Model Pembelajaran Numbered Head Together (NHT) Dengan Media Teka-Teki Silang Terhadap Hasil Belajar Tematik Siswa
}

\author{
Umi Atiyah ${ }^{1 *}$, Mei Fita Asri Untari², Ahmad Nashir Tsalatsa ${ }^{3}$ \\ 1,2,3Jurusan Pendidikan Guru Sekolah Dasar, Fakultas Ilmu Pendidikan,Universitas PGRI Semarang
}

\author{
A R T I C LE I N F O \\ Article history: \\ Received 18 Desember \\ 2017 \\ Received in revised form \\ 30 Desember 2017 \\ Accepted 15 Januari 2018 \\ Available online 27 \\ Februari 2018

\section{Kata Kunci:} \\ ematik, model pembelajaran \\ Numbered Head Together \\ (NHT), hasil belajar. \\ Keywords: \\ Thematic, Numbered Head \\ Together (NHT) learning \\ model, learning outcomes
}

\begin{abstract}
A B S T R A K
Penelitian ini dilatarbelakangi oleh kurangnya minat belajar siswa yang berakibat tidak tercapainya nilai KKM. Tujuan penelitian ini adalah mengetahui keefektifan model Numbered Head Together (NHT) dengan media teka-teki silang terhadap hasil belajar tematik siswa kelas IV SDN Pandean Lamper 04 Semarang. Jenis penelitian ini adalah kuantitatif dengan metode eksperimen dan desain Pre-Experimental Design. Bentuk desain penelitian yang digunakan adalah one-group pretest-posttest design. Populasi penelitian ini adalah seluruh siswa kelas IV SDN Pandeanlamper 04 Semarang dengan jumlah 21 siswa. Jumlah sampel sebanyak 21 siswa dengan menggunakan teknik Nonprobability Sampling jenis sampling jenuh. Data dalam penelitian ini diperoleh melalui teknik tes. Hasil nilai rata-rata pretest dan posttest mengalami peningkatan. Pada nilai pretest diperoleh nilai rata-rata sebesar 49,94 dan nilai posttest diperoleh nilai sebesar 80,61. Dengan demikian terjadi peningkatan hasil belajar tematik siswa menggunakan Model Pembelajaran Numbered Head Together (NHT) dengan Media Teka-Teki Silang. Hasil pengujian hipotesis pada hasil belajar siswa aspek kognitif menunjukkan bahwa thitung 10,979 dan ttabel 2,101 dengan taraf signifikan $5 \%$. Karena thitung > ttabel, yaitu 10,979 >
\end{abstract} 2,101 sehingga $\mathrm{HO}$ ditolak. Karena HO ditolak, maka kesimpulannya yaitu Model Pembelajaran Numbered Head Together (NHT) dengan Media Teka-Teki Silang efektif terhadap Hasil Belajar Tematik Siswa Kelas IV SDN Pandean Lamper 04 Semarang.

\section{A B S T R A C T}

This research is motivated by a lack of student learning interest which results in not achieving KKM values. The purpose of this study was to determine the effectiveness of the Numbered Head Together (NHT) model with a crossword media on the thematic learning outcomes of fourth grade students of SDN Pandeanlamper 04 Semarang. This type of research is quantitative with experimental methods and Pre-Experimental Design. The form of research design used is one-group pretestposttest design. The population of this study was all fourth grade students of SDN Pandeanlamper 04 Semarang with a total of 21 students. The number of samples is 21 students using the nonprobability sampling technique which is a saturated type. The data in this study were obtained through test techniques. The results of the average pretest and posttest values increased. At the pretest value obtained an average value of 49.94 and the posttest value obtained a value of 80.61 . Thus an increase in thematic learning outcomes of students using Numbered Head Together (NHT) Learning Model with Cross Puzzle Media. The results of hypothesis testing on cognitive learning outcomes of students showed that tcount 10,979 and $t$ table 2,101 with a significant level of $5 \%$. Because $t$ count> $t$ table, which is $10,979>2,101$ so that $\mathrm{HO}$ is rejected. Because $\mathrm{HO}$ is rejected, the conclusion is Numbered Head Together (NHT) Learning Model with Cross-Puzzle Media effective against Thematic Learning Outcomes of Grade IV Students of SDN Pandeanlamper 04 Semarang.

Copyright (C) Universitas Pendidikan Ganesha. All rights reserved.

\footnotetext{
${ }^{1}$ Corresponding author.

E-mail addresses: Umiatiyah50@gmail.com (Umi Atiyah)
} 


\section{Pendahuluan}

Pendidikan merupakan faktor utama dalam pembentukan pribadi manusia. Pendidikan juga merupakan salah satu komponen yang sangat menentukan kualitas suatu bangsa. Kegagalan pendidikan berdampak pada gagalnya suatu bangsa, keberhasilan pendidikan juga secara otomatis membawa keberhasilan sebuah bangsa. Berbagai upaya digunakan untuk memajukan pendidikan dimulai dari pengembangan kurikulum sampai pada cara mengajar guru yang semakin lama semakin disempurnakan.

Hal tersebut sejalan dengan Undang-Undang RI Nomor 20 Tahun 2003 tentang Sistem Pendidikan Nasional Bab 1 Pasal 1, pendidikan adalah usaha sadar dan terencana untuk mewujudkan suasana belajar dan proses pembelajaran agar peserta didik secara aktif mengembangkan potensi dirinya untuk memiliki kekuatan spiritual, keagamaan, pengendalian diri, kepribadian, kecerdasan, akhlak mulia, serta keterampilan yang diperlukan dirinya, masyarakat, bangsa dan negara. Berlandaskan kutipan tersebut, guru merupakan seorang yang dapat menentukan kemajuan bangsa dengan cara mencerdaskan peserta didik agar berguna untuk bangsanya.

Saat ini Kementrian Pendidikan dan Budaya telah menerapkan kurikulum baru yaitu kurikulum 2013. Dalam kurikulum 2013, materi disajikan dalam bentuk tematik. Menurut Daryanto (2014:3) pembelajaran tematik diartikan sebagai pembelajaran yang menggunakan tema untuk mengaitkan beberapa mata pelajaran sehingga dapat memberikan pengalaman bermakna kepada siswa.

Pembelajaran tematik menekankan pula pada penerapan konsep belajar sambil melakukan. Dalam hal ini peserta didik dituntut untuk aktif selama proses pembelajaran berlangsung. Oleh karena itu, guru harus mampu mengemas dan merancang suatu kegiatan belajar dengan menggunakan strategi pembelajaran yang inovatif dan bervariasi sehingga peserta didik tertarik dan merasa senang dalam mengikuti proses pembelajaran. Namun pada kenyataanya, masih banyak pembelajaran tematik yang berpusat pada guru. Dimana guru hanya menggunakan model pembelajaran ceramah dan penugasan. Dengan model pembelajaran tersebut, maka peserta didik akan pasif dalam pembelajaran karna hanya sebatas mendengarkan penjelasan guru. Selain itu, membuat peserta didik kurang memahami materi karena materi diberikan oleh guru tanpa melibatkan peserta didik secara aktif.

Berdasarkan hasil observasi yang dilakukan peneliti di kelas IV SDN Pandean Lamper 04 Semarang pada saat magang II, dapat diketahui jika guru masih menggunakan metode pembelajaran ceramah dan penugasan. Peserta didik belum dilibatkan secara langsung dalam pembelajaran sehingga banyak peserta didik yang berbicara dengan temannya, bermain sendiri dan mengganggu teman sebelahnya. Kegiatan tersebut membuat peserta didik tidak fokus dalam kegiatan pembelajaran yang ditandai dengan perilaku peserta didik yang tidak mampu menjawab pertanyaan dari guru. Hal tersebut dikarenakan pembelajaran masih berpusat pada guru sehingga peserta didik merasa jenuh dan bosan dalam proses pembelajaran yang berlangsung. Sehingga dengan proses pembelajaran yang seperti itu dapat mengakibatkan kurangnya minat siswa untuk belajar yang dapat mempengaruhi hasil belajar siswa rendah yaitu hanya $60 \%$ siswa yang mencapai KKM yang telah ditentukan.

Kesulitan yang dialami peserta didik dalam memahami materi dapat disebabkan oleh beberapa faktor, salah satunya yaitu model pembelajaran yang digunakan oleh guru. Salah satu model yang inovatif dan dapat melibatkan siswa secara aktif dalam proses pembelajaran yaitu dengan menerapkan model pembelajaran kooperatif tipe Numbered Head Together (NHT). Model pembelajaran kooperatif tipe Numbered Head Together (NHT) cocok diterapkan pada pembelajaran tematik karena dapat melibatkan semua siswa secara aktif bukan hanya satu atau dua orang saja. Model pembelajaran Numbered Head Together (NHT) pada dasarnya merupakan varian dari diskusi kelompok (Huda, 2013:203). Melalui model ini diharapkan peserta didik mampu mengemukakan pemikirannya, saling bekerja sama dalam satu kelompok dan saling bertukar pendapat.

Berdasarkan hasil penjelasan yang disampaikan oleh Ibu Ngatinah bahwa dalam mengajar tematik masih menggunakan metode ceramah serta penugasan. Adapun kendala yang dialami yaitu terbatasnya media pembelajaran yang digunakan dalam pembelajaran tematik. Siswa merasa kurang tertarik dan cenderung pasif selama proses pembelajaran berlangsung. Oleh karena itu, guru perlu menggunakan media pembelajaran yang nyata dan dapat menarik perhatian siswa. Salah satu media yang dapat digunakan yaitu media teka-teki silang. Dengan media teka-teki silang tersebut, siswa merasa tertantang dalam menjawab pertanyaan yang berkaitan dengan materi pembelajaran yang telah dipelajari dan melibatkan pemikiran siswa sehingga dapat diketahui sejauh mana pemahaman peserta didik terhadap materi yang telah disampaikan oleh guru. Dengan model pembelajaran Numbered Head Together (NHT) dan media teka-teki silang diharapkan pembelajaran dapat bermakna dan menghasilkan pemahaman yang kuat bagi siswa.

Hal ini diperkuat dengan penelitian Ferawati (2018) dengan judul "Keefektifan Media PANIKER (Papan Jenis-jenis Pekerjaan) Berbantu Model NHT Terhadap Hasil Belajar Siswa Kelas III Pada Mata 
Pelajaran IPS MI Asy-Syafi'iyah Jepara" terbukti bahwa model Numbered Head Together NHT efektif dalam meningkatkan hasil belajar siswa. Hal tersebut dibuktikan hasil pada pre-test sebelum dikenai perlakukan, hasil belajar siswa hanya mencapai 35\% nilai dari KKM, dan setelah dikenai perlakukan dan diberikannya post-test hasil belajar siswa naik menjadi 95\% nilai dari KKM. Penelitian oleh Witari (2017) menyatkan bahwa pembelajaran dengan model pembelajaran kooperatif tipe Numbered Head Together (NHT) berpengaruh positif terhadap hasil belajar IPA siswa Kelas IV di SDN Gugus I Kecamatan Sawan Tahun Pelajaran 2016/107.

Penelitian ini memiliki persamaan dan perbedaan dengan penelitian yang relevan diatas. Persamaan penelitian ini dengan penelitian yang relevan diatas yaitu sama-sama menggunakan model pembelajaran Numbered Head Together (NHT) untuk meningkatkan hasil belajar siswa. Perbedaannya adalah penelitian ini menggunakan model pembelajaran Numbered Head Together (NHT) dengan media teka-teki silang yang digunakan dalam pembelajaran tematik kelas IV SD.

Menurut Rusman (2017 : 215) hakikatnya media pembelajaran sebagai wahana untuk menyampaikan pesan atau informasi dari sumber pesan diteruskan pada penerima. Pesan atau bahan ajar yang disampaikan adalah materi pembelajaran untuk mencapai tujuan pembelajaran atau sejumlah kompetensi yang telah dirumuskan, sehingga dalam prosesnya memerlukan media sebagai subsistem pembelajaran. Media pembelajaran adalah alat yang dapat membantu proses belajar mengajar dan berfungsi untuk memperjelas makna pesan yang disampaikan, sehingga dapat mencapai tujuan pembelajaran dengan lebih baik dan sempurna (Kustandi \& Sutjipto, 2011: 9).

Penelitian ini bertujuan untuk mengetahui hasil belajar tematik siswa pada penerapan model pembelajaran Numbered Head Together (NHT) dengan media teka-teki silang siswa kelas IV SDN Pandeanlamper 04 Semarang. Trianto $(2017$ : 131) menyatakan bahwa Numbered Head Together (NHT) atau penomoran berpikir bersama merupakan jenis pembelajaran kooperatif yang dirancang untuk memengaruhi pola interaksi siswa dan sebagai alternatif terhadap struktur kelas tradisional. Susanto (2013:5) mengatakan bahwa hasil belajar yaitu perubahan-perubahan yang terjadi pada diri siswa, baik yang menyangkut aspek kognitif, afektif, dan psikomotor sebagai hasil dari kegiatan belajar. Sedangkan menurut Rusman (2017 : 129) hasil belajar adalah sejumlah pengalaman yang diperoleh siswa yang mencakup ranah kognitif, afektif, dan psikomotorik.

\section{Metode}

Jenis penelitian ini adalah kuantitatif dengan metode eksperimen dan desain Pre-Experimental Design. Bentuk desain penelitian yang digunakan adalah one-group pretest-posttest design. Populasi dalam penelitian ini adalah seluruh siswa kelas IV SDN Pandean Lamper 04 Semarang. Sampel dalam penelitian ini adalah seluruh siswa kelas IV SDN Pandean Lamper 04 Semarang yang berjumlah 21 siswa. Teknik sampling yang digunakan dalam penelitian ini adalah Nonprobability Sampling jenis sampling jenuh.

Teknik pengumpulan data yang digunakan dalam penelitian ini adalah tes, dokumentasi, wawancara dan observasi. Instrumen penelitian menggunakan tes berupa soal pilihan ganda. Instrumen tes diuji sebelum digunakan dalam penelitian untuk mengetahui validitas, reliabilitas, tingkat kesukaran dan daya pembeda. Uji coba instrumen yang telah dilakukan di SDN Tambakrejo 02 Semarang pada tanggal 22 Oktober 2018 dengan jumlah soal pilihan ganda sebanyak 50 soal dengan jumlah siswa sebanyak 20 siswa.

Analisis data awal didapat dari nilai pretest pada aspek kognitif siswa, sebagai tolak ukur untuk analisis data awal sebagai penilaian hasil belajar. Analisis awal ini meliputi uji normalitas awal untuk menggetahui apakah nilai pretest berasal dari sampel yang berdistribusi normal atau tidak. Uji normalitas menggunakan uji Lilliefors. Uji normalitas akhir digunakan untuk mengetahui apakah nilai posttest berasal dari sampel yang berdistribusi normal atau tidak. Uji normalitas menggunakan uji Lilliefors. Setelah kedua data dinyatakan berdistribusi normal, maka data dianalisis menggunakan Uji-t

\section{Hasil dan Pembahasan}

Peneliti melakukan penelitian di SDN Pandeanlamper 04 Semarang tepatnya di kelas IV dengan jumlah siswa 21 siswa yang terdiri dari 13 siswa laki-laki dan 8 siswa perempuan. Namun terdapat 3 siswa yang tidak mengikuti pembelajaran dikarenakan informasi dari guru kelas bahwa dua siswa sudah tidak pernah berangkat sekolah namun belum ada keterangan keluar dari sekolah dan satu siswa tidak masuk sekolah. Peneliti menggunakan metode Pre-Experimental Design dengan bentuk One-Group PretestPosttest Design. Peneliti melaksanakan penelitian sebanyak enam kali pembelajaran. Peneliti mengolah hasil belajar siswa untuk mengetahui sejauh mana kemajuan hasil belajar siswa baik sebelum diberi 
perlakuan (pretest) maupun setelah diberi perlakuan (posttest). Data awal diambil dari hasil nilai pretest sedangkan data akhir diambil dari hasil nilai posttest.

Hasil penelitian diperoleh dari nilai pretest dan nilai posttest. Nilai pretest dan nilai posttest dinyatakan tuntas apabila mencapai KKM 70. Dalam penelitian ini hasil nilai pretest berbeda dengan hasil nilai posttest, karena nilai posttest didapat setelah siswa diberikan perlakuan. Berikut Tabel 1 hasil nilai pretest siswa kelas IV SDN Pandeanlamper 04 Semarang.

Tabel 1. Data Hasil Pretest Siswa

\begin{tabular}{cc}
\hline Kriteria & Nilai Siswa \\
\hline Nilai Tertinggi & 80 \\
Nilai Terendah & 20 \\
Nilai Rata-rata & 49,94 \\
\hline &
\end{tabular}

Berdasarkan data yang terdapat pada Tabel 1 Data Hasil Pretest Siswa diperoleh data siswa yang diteliti pada kelas IV SDN Pandeanlamper 04 Semarang sebanyak 18 siswa. Data awal penelitian diperoleh dari hasil nilai pretest siswa, dengan memperoleh data nilai rata-rata hasil belajar sebesar 49,94 dengan nilai tertinggi 80 dan nilai terendah 20 . Untuk lebih mempermudah pemahaman hasil data maka dapat dilihat pada gambar diagram dibawah ini :

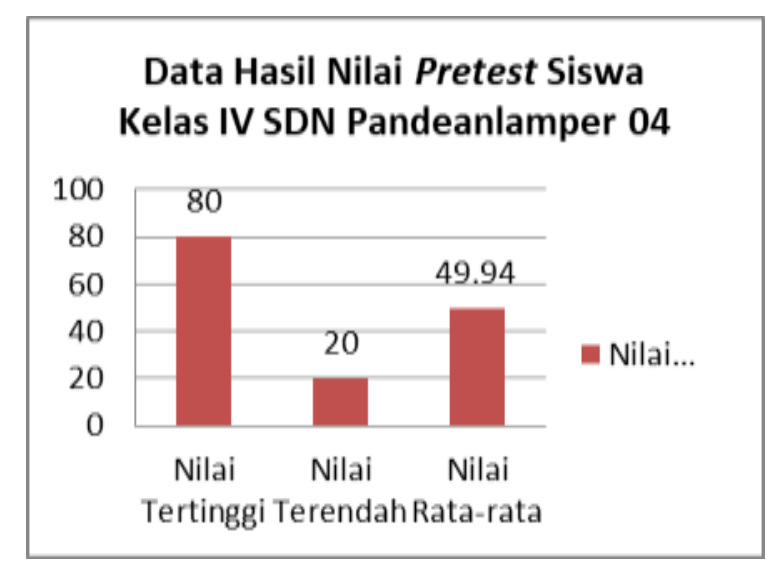

Gambar 1. Data Hasil Nilai Pretest Siswa Kelas IV SDN Pandeanlamper 04

Berdasarkan Gambar Diagram 1. Data Hasil Nilai Pretest Siswa Kelas IV SDN Pandeanlamper 04 menunjukkan bahwa data nilai hasil pretest memperoleh nilai tertinggi yang sudah mampu mencapai ketuntasan minimum. Tetapi, nilai terendah dan nilai rata-rata masih jauh dari KKM yaitu 70.

Data akhir penelitian diperoleh dari hasil posttest siswa. Perlakuan yang diberikan yaitu menggunakan model pembelajaran Numbered Head Together (NHT) dengan media teka-teki silang. Nilai hasil Posttest diperoleh setelah diterapkannya model pembelajaran Numbered Head Together (NHT) dengan media teka-teki silang. Berikut data hasil posttest dapat dilihat pada Tabel 2 di bawah ini :

Tabel 2. Data Hasil Posttest Siswa

\begin{tabular}{cc}
\hline Kriteria & Nilai Siswa \\
\hline Nilai Tertinggi & 100 \\
Nilai Terendah & 60 \\
Nilai Rata-rata & 80,61 \\
\hline
\end{tabular}

Sumber : Data Hasil Penelitian (2018)

Berdasarkan data yang terdapat pada Tabel 2. Data Hasil Posttest Siswadiperoleh data siswa yang diteliti pada kelas IV SDN Pandeanlamper 04 Semarang sebanyak 18 siswa. Data akhir penelitian diperoleh dari hasil nilai posttest siswa, dengan memperoleh data nilai rata-rata hasil belajar sebesar 80,61 dengan nilai tertinggi 100 dan nilai terendah 60. Untuk lebih mempermudah pemahaman hasil data maka dapat dilihat pada gambar diagram di bawah ini : 


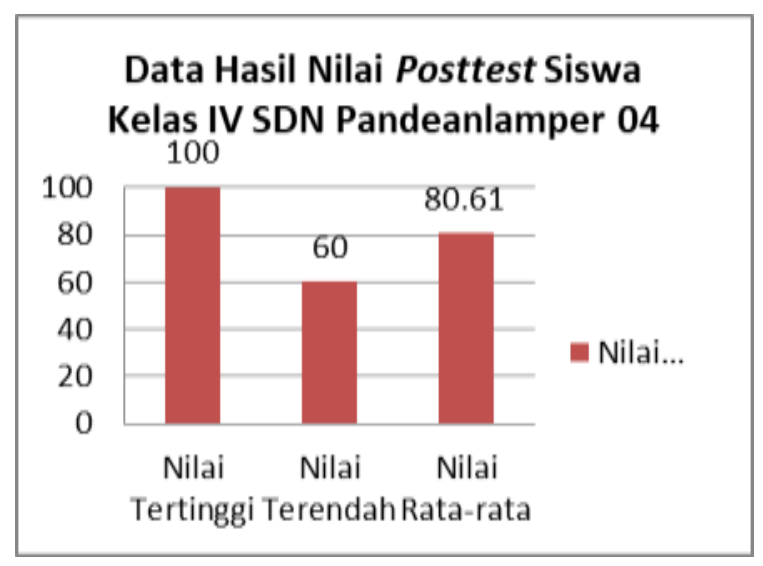

Gambar 2. Data Hasil Nilai Posttest Siswa Kelas IV SDN Pandeanlamper 04

Dari Gambar 2. Data Hasil Nilai Posttest Siswa Kelas IV SDN Pandeanlamper 04 menunjukkan bahwa data nilai tertinggi sudah mampu mencapai KKM, nilai terendah dan nilai rata-rata juga meningkat meskipun masih terdapat 3 siswa yang belum mampu mencapai KKM 70.

Setelah mendapatkan data tersebut kemudian dilakukan analisis data, yaitu uji normalitas hasil pretest dan posttest dari kelas IV SDN Pandeanlamper 04 Semarang. Uji normalitas awal yang berasal dari nilai pretest siswa didapatkan hasil $\mathrm{L}_{0}<\mathrm{L}_{\text {tabel }}$ yaitu $(0,1053<0,200)$, maka $\mathrm{H}_{0}$ diterima atau sampel data awal pretest berdistribusi normal.

Uji normalitas akhir menggunakan data akhir penelitian yang menggunakan nilai posttest siswa kelas IV SDN Pandeanlamper 04 Semarang. Hasil perhitungan menyatakan bahwa nilai posttest siswa berdistribusi normal. Hal tersebut dibuktikan hasil perolehan perhitungan $\mathrm{L}_{0}<\mathrm{L}_{\text {tabel }}$ yaitu $(0,1078<0,200)$, maka $\mathrm{H}_{0}$ diterima atau sampel data akhir posttest berdistribusi normal.

Setelah uji normalitas awal dan akhir, selanjutnya dilakukan analisis uji-t satu pihak dengan membandingkan hasil belajar pretest dan posttest, diperoleh $t_{\text {hitung }} 10,976$. Kemudian dibandingkan dengan harga $t_{\text {tabel }}=2,101$ pada taraf signifikan $5 \%$. Kriteria pengujian hipotesis adalah $\mathrm{H}_{0}$ diterima apabila $t_{\text {hitung }}<t_{\text {tabel. }}$. Pada hasil perhitungan diperoleh $t_{\text {hitung }}>t_{\text {tabel, }}$ yaitu $10,979>2,101$, sehingga $H_{0}$ ditolak. Karena $\mathrm{H}_{0}$ ditolak, maka kesimpulannya yaitu Model pembelajaran Numbered Head Together (NHT) dengan media teka-teki silang efektif untuk meningkatkan hasil belajar tematik siswa kelas IV SDN Pandean Lamper 04 Semarang.

Berdasarkan hasil penelitian menunjukkan bahwa Model Pembelajaran Numbered Head Together (NHT) dengan media teka-teki silang efektif untuk meningkatkan hasil belajar tematik siswa kelas IV SDN Pandeanlamper 04 Semarang. Dengan hasil belajar meningkat dibandingkan pembelajaran yang tidak menggunakan Model Pembelajaran Numbered Head Together (NHT) dengan media teka-teki silang. Hasil nilai pretest siswa sebelum diberi pembelajaran menggunakan Model Pembelajaran Numbered Head Together (NHT) dengan media teka-teki silang mendapatkan nilai rata-rata sebsar 49,94 terdapat 4 siswa yang telah mencapai KKM dan 14 siswa yang belum mencapai KKM. Sedangkan hasil nilai hasil posttest siswa setelah diberikan perlakuan mendapatkan nilai rata-rata 80,61 terdapat 15 siswa yang telah mencapai KKM dan 3 siswa yang belum mencapai KKM. Penelitian ini dikuatkan oleh penelitian sebelumnya yang dilakukan oleh Rika Fima Yenni (2016) menyatakan Berdasarkan hasil perhitungan menggunakan software minitab diperoleh $\mathrm{P}$-value $=0,016$ pada taraf kepercayaan $95 \%(\alpha=0,05)$. Karena P-value $<\alpha$ maka tolak H0 dan terima H1. Ini berarti hasil belajar matematika siswa yang menggunakan metode NHT lebih baik dari pada hasil belajar matematika siswa yang menggunakan pembelajaran konvensional. Nursyamsi SY (2016) menyatakan dari perbandingan rerata terkoreksi diketahui bahwa strategi pembelajaran NHT memberikan pengaruh lebih besar, yaitu sebesar 21,56\%, dibandingkan pengaruh yang disebabkan oleh pembelajaran konvensional. Mutia Agisni Mulyana (2016) Menyatakan bahwa Model kooperatif tipe Numbered Heads Together (NHT) dapat meningkatkan hasil belajar siswa pada materi kenampakan alam dan sosial budaya. Siti Nuryanti (2014) juga menyatakan penerapan model pembelajaran kooperatif tipe Numbered Head Together dapat meningkatkan hasil belajar IPA siswa Kelas IV SD Negeri 3 Tondo Palu.

Widodo (2013) menyatakan terkait hasil belajar bahwa dengan menggunakan metode pembelajaran berbasis masalah dapat meningkatkan kegiatan pembelajaran dan hasil belajar siswa. Monawati (2016) juga menyatakan bahwa upaya meningkatkan Hasil Belajar Siswa melalui Lesson Study pada Penjumlahan Pecahan di Kelas IV SDN Lamsayeun. Pukjiwati (2017) menyatakan penelitian pendekatan CTL ini dapat meningkatkan kualitas hasil belajar siswa terhadap mata pelajaran Matematika 
tentang Operasi Hitung Pecahan dalam Pemecahan Masalah kelas IV SD Negeri Sumur 03, Kecamatan Cluwak, Kabupaten Pati, melalui media belajar dan mengajar.

\section{Simpulan dan Saran}

Berdasarkan rumusan masalah, hipotesis, analisis data penelitian, dan pembahasan, maka diperoleh kesimpulan bahwa Model Pembelajaran Numbered Head Together (NHT) dengan Media TekaTeki Silang dapat meningkatkan hasil belajar siswa pada tema 4 berbagai pekerjaan subtema 2 pekerjaan disekitarku kelas IV SDN Pandeanlamper 04 Semarang, dengan rincian sebagai berikut:

Setelah dilakukan pengujian hipotesis dengan analisis hasil belajar siswa subtema pekerjaan disekitarku pada ranah pengetahuan diperoleh nilai rata-rata kelas untuk pretest sebesar 49,94 dan posttest sebesar 80,61 dengan $\mathrm{n}=18$ sehingga diperoleh thitung $=10,976$ dengan taraf signifikansi $5 \%$ didapat nilai ttabel $=2,101$. Karena thitung $(10,976)>$ ttabel $(2,101)$ maka H0 ditolak dan Ha diterima. Sehingga dapat dikatakan bahwa Model Pembelajaran Numbered Head Together (NHT) dengan Media Teka-Teki Silang secara signifikan efektif untuk meningkatkan hasil belajar tematik siswa kelas IV SDN Pandeanlamper 04 Semarang. Jadi terdapat perbedaan nilai posttest Subtema Pekerjaan Disekitarku kelas IV SDN Pandeanlamper 04 Semarang sesudah menggunakan Model Pembelajaran Numbered Head Together (NHT) dengan Media Teka-Teki Silang.

\section{Daftar Rujukan}

Astrawan, I Gede Budi .2012."Penerapan Model Kooperatif Tipe NHT Dalam Meningkatkan Hasil Belajar Siswa Pada Mata Pelajaran IPA Di Kelas V SD N 3 Tonggolobibi. Jurnal Kreatif Tadulako Online Vol. 3 No. 4ISSN 2354-614X

Daryanto. 2014. Pembelajaran Tematik, Terpadu, Terintegrasi (kurikulum 2013). Yogyakarta : Penerbit Gava Media.

Ferawati (2018) dengan judul "Keefektifan Media PANIKER(Papan Jenis-jenis Pekerjaan) Berbantu Model NHT Terhadap Hasil Belajar Siswa Kelas III Pada Mata Pelajaran IPS MI Asy-Syafi'iyah Jepara". Skripsi : Semarang : Universitas PGRI Semarang.

Huda, Miftahul. 2017. Model-Model Pengajaran Dan Pembelajaran Isu-Isu Metodis Dan Paradigmatis. Yogyakarta : PUSTAKA PELAJAR.

Kustandi dan Sutjipto. 2011. Media Pembelajaran Manual dan Digital. Bogor : Ghalia Indonesia.

Monawati, M. Yamin. 2016. Upaya Meningkatkan Hasil Belajar Siswa Melalui Lesson Study Pada Penjumlahan Pecahan Di Kelas IV Sdn Lamsayeun. JURNAL PESONA DASAR Universitas Syiah Kuala. Vol. 3 No.4, Oktober.

Mutia Agisni Mulyana, Nurdinah Hanifah, Asep Kurnia Jayadinata. 2016. Penerapan Model Kooperatif Tipe Numbered Heads Together (NHT) Untuk Meningkatkan Hasil Belajar Siswa Pada Materi Kenampakan Alam Dan Sosial Budaya. Jurnal Pena Ilmiah UPI. Vol 1 No 1.

Nursyamsi SY, Aloysius Duran Corebima, Herawati Susilo. 2016. Pengaruh Strategi Pembelajaran Numbered Heads Together (NHT) terhadap Hasil Belajar Siswa SMA Negeri 1 Muara Badak. Jurnal Pendidikan: Teori, Penelitian, dan Pengembangan. Vol 1 No 10 Edisi Oktober.

Pukjiwati. 2017. Upaya Meningkatkan Aktivitas Hasil Belajar Siswa Pada Materi Pecahan Dengan Pendekatan Contextual Teaching and Learning Kelas IV SDN Sumur 03. JURNAL REFLEKSI EDUKATIKA Universitas Muria Kudus. Volume 7 (2).

Rika Fima Yenni. 2016. Penggunaan Metode Numbered Head Together (NHT) Dalam Pembelajaran Matematika. Jurnal Penelitian dan Pembelajaran Matematika. Jurnal Penelitian dan Pembelajaran Matematika. Vol 9 No 2.

Rusman. 2017. Belajar dan Pembelajaran Berorientasi Standar Proses Pendidikan. Jakarta : KENCANA. 
Siti Nuryanti. 2014. Penerapan Model Pembelajaran Kooperatif Tipe Numbered Head Together (Nht) Untuk Meningkatkan Hasil Belajar Siswa Pada Mata Pelajaran Ipa Kelas IV Sd Negeri 3 Tondo. Jurnal Diknas. Volume 2 No 2.

Sugiyono. 2016. Metode Penelitian Pendidikan Pendekatan Kuantitatif, Kualitatif, dan R\&D. Bandung : Alfabeta.

Susanto, Ahmad. 2016. Teori Belajar Dan Pembelajaran Di Sekolah Dasar. Jakarta : Kencana.

Trianto. 2017. Mendesain Model Pembelajaran Inovatif, Progresif, Dan Kontekstual : Konsep Landasan, dan Implementasinya pada Kurikulum 2013 (Kurikulum Tematik Integratif/KTI).Jakarta : PT. Kharisma Putra Utama.

Widodo, Lusi Widayanti. 2013. Peningkatan Aktivitas Belajar Dan Hasil Belajar Siswa Dengan Metode Problem Based Learning Pada Siswa Kelas Viia Mts Negeri Donomulyo Kulon Progo. Jurnal Fisika Indonesia No: 49, Vol XVII, Edisi April.

Witari, I Gusti Ayu. 2017. Pengaruh Model Pembelajaran Kooperatif Tipe Numbered Head Together (NHT) Terhadap hasil Belajar IPA Siswa Kela IV di SDN Gugus I Kecamatan sawan Tahun Pelalajaran 201/2017. Jurnal MImbar PGSD Universitas Pendidikan Ganesha Volume 3 Nmor 4. 